


\title{
STATUS OF CONCENTRATOR COLLECTOR AND HIGH-EFFICIENCY CONCENTRATOR CELL DEVELOPMENT
}

James M. Gee

SAND $--90-2598 \mathrm{C}$

DE9 1001260

Sandia National Laboratories

Albuquerque, NM 87185

Photovoltaic concentrator collectors are an attractive option for utility-scale photovoltaic power plants. This paper reviews the current status of photovoltaic concentrator collector and cell development. Included in the review is a discussion of the economic motivation for concentrators, a summary of recent concentrator collector and cell development, and a description of a major new program to accelerate development and commercial introduction of concentrator coliectors.

Submitted for publication in Technical Digest 5th International Photovoltaic science and Engineering Conference, Kyoto, Japan, November $26-30,1990$.

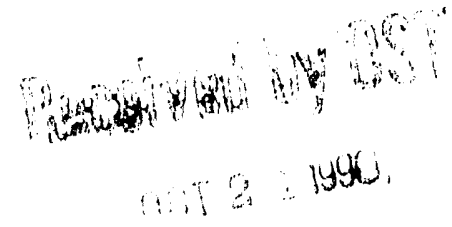

\section{DISCLAIMER}

\begin{abstract}
This report was prepared as an account of work sponsored by an agency of the United States Government. Neither the United States Government nor any agency thereof, nor any of their employees, makes any warranty, express or implied, or assumes any legal liability or responsibility for the accuracy, completeness, or usefulness of any information, apparatus, product, or process disclosed, or represents that its use would not infringe privately owned rights. Reference herein to any specific commercial product, process, or service by trade name, trademark, manufacturer, or otherwise does not necessarily constitute or imply its endorsement, recommendation, or favoring by the United States Government or any agency thereof. The views and opinions of authors expressed herein do not necessarily state or reflect those of the United States Government or any agency thereof.
\end{abstract}

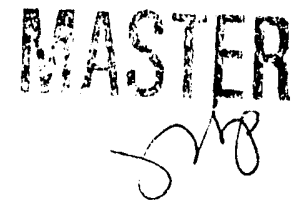




\section{Introduction}

The long-term goal of the United states photovoltaic solar energy program managed by the Department of Energy (DOE) is to help establish photovoltaic-derived energy as a significant energy source for the United States. Cost goals for photovoltaic modules were established by DOE on the basis that photovoltaic energy would need to be cost-competitive with other utility power generation technologies. These goals in terms of levelized energy cost are $12 \% / \mathrm{kWh}$ for the near-term (mid-1990) and $6 \mathrm{c} / \mathrm{kWh}$ for the long-term (year 2000). These goals are in constant 1986 \$US; details are presented in DOE's Five-Year Research Plan, 1987-1991 (1). The near-term goal of $12 \mathrm{c} / \mathrm{kWh}$ is competitive with present utility peak-power generation costs, and thus represents an entry point for photovoltaics into the utility market.

These levelized-energy-cost goals are very ambitious. For example, the longterm goal of $6 \% / \mathrm{kWh}$ requires that one-sun modules cost less than $100 \$ / \mathrm{m}^{2}$. Since the solar cell represents approximately $50 \%$ of the cost of a one-sun module, a one-sun solar cell needs to eventually cost less than $0.5 \mathrm{c} / \mathrm{cm}^{2}$. Note that the cost of the crystalline silicon wafers in present one-sun modules is over $1 \mathrm{c} / \mathrm{cm}^{2}$ by itself. Novel thin-film materials (e.g. silicon film, a-Si:H, CuInse, cdTe, etc.) and silicon ribbon are under development by several

Prepared by Sandia National Laboratories, Albuquerque, NM and Livermore, CA, operated for the U.S. Department of Energy under contract DE-ACO4-76DP00789. 
organizations to meet the ambitious longterm goal. Another approach is to concentrate the solar energy onto the solar cell by means of concentrator optics. In effect, concentrator photovoltaic systems replace relatively expensive electronic material. (solar cell) with less expensive optical materials (lens or reflector).

This paper reviews the status of: concentrator photovoltaic technology development in the United States. We first discuss the economic motivation for concentrator collectors and for high efficiencies. We next review the status of concentrator collector technology and of high-efficiency concentrator celis. Finaliy, we conclude with a brief description of a new initiative to accelerate development of concentrator collectors.

\section{Economics of photovoltaic Collectors}

The mid-1990 energy cost goals can be translated into module cost goals given certain assumptions about balance-ofsystem costs, operation and maintenance costs, solar resource, system lifetime, and other financial factors. Using the assumptions in the DOE Five-Year Research Plan, allowable module costs that meet a levelized-energy-cost goal of $12 \mathrm{c} / \mathrm{kWh}$ were calculated (Table 1). The module and cell costs 1 isted in Table 1 are the maximum selling prices from the perspective of a module or cell vendor. The table is separated into four categories: one-sun collectors and concentrator collectors with three different ranges for the geometric concentration ratio (low, mid, or high). The cell cost/effi- 
ciency combinations for each category are believed to be achievable. The allowable cell costs assume half and one-third of the cost of a onesun and of a concentrator module, respectively.

The module cost goals in $\$ / \mathrm{m}^{2}$ for the concentrator collectors are lower than the corresponding goals for one-sun modules. This is due to two factors: (1) there is less solar insolation available to concentrator collectors, which colj. c only the direct portion of the solar insolation; and (2) there are higher area-related balance-of-system costs and operation and maintenance costs for concentrator collectors due to the requirement for accurate two-axis tracking.

The strength of the concentrator approach is that the cost constraints on the solar cell are significantly relaxed. Whereas the cost of one-sun solar cells needs to be less than $1 \mathrm{c} / \mathrm{cm}^{2}$, allowable concentrator cell costs range from $4 \mathrm{c} / \mathrm{cm}^{2}$ for a low-X concentrator collector, up to $12 \$ / \mathrm{cm}^{2}$ for a high-X concentrator collector. In addition to the concentration ratio, the allowable cell cost is very sensitive to the cell efficiency (Figure 1). Consider, for example, a $24 \%$ and a $30 \%$ efficient cell in a concentrator module with a geometric concentration ratio of $400 \mathrm{x}$. The allowable cell cost increases by $43 \%$ for a cell that is only 25\% more efficient.

Chamberlin has recently completed a survey of concentrator module developers on the manufacturing costs of concentrator modules (3). The survey examined projected module costs for different production volumes. Costs for different concentrator module components (e.g. cell, cell assembly, optics, housing, etc.) were generaliy based on established technologies and are therefore fairly reliable. For example, estimates for an aluminum housing were based on vendor quotes for aluminum formed by techniques (deep drawn) already widely used in industry for other applications. This is in contrast with many of the thin-film technologies where the production technology is still in development. The conclusion of the study is that concentrator collectors are capable of meeting the DOE near-term cost goal of $12 \mathrm{c} / \mathrm{kWh}$ at 
large production volumes ( $>10 \mathrm{MW} / \mathrm{Yr}$ ) if concentrator cell cost and performance goals could be met.

It should be noted that solar concentrator thermal systems have a large installed capacity base ( $350 \mathrm{MW}$ ) in the United Staces, so that issues regarding siting, tracking, and operation and maintenance costs are not considered significant obstacles for solar concentrator collectors. In fact, the primary obstacle facing all photovoltaic systems is the cost of the photovoltaic collector itself $(1,4)$.

\section{Concentrator collectors}

A concentrator collector refers to the basic energy producing subsystem. It consists of the concentrator optics, cell and cell assembly, and support structure. A wide variety of concentrator collectors have been proposed and/or investigated over the years. The optical systems can be either refractive or reflective and the geometric concentration ratio can range from low (2X) to high (2000X) values. Most concentrator systems require two-axis tracking, although some low-concentration systems use single-axis tracking. static concentrator systems, which do not use any tracking, have also been proposed. The size of the concentrator optical element also can span a wide range. Most systems use a lens for the primary concentrating optical element; these lenses can range from 1.6 $\mathrm{cm}^{2}$ up to $3 \mathrm{~m}^{2}$. Reflective dish collectors and heliostat fields with a central receiver have also been investigated. These systems concentrate the solar energy onto a receiver that consists of an array of cells ("dense-packed array").

There are at least 16 different concentrator collectors actively under development in the United States (Table 2). The large number of developers demonstrates significant interest in photovoltaic concentrator collector technology. The concentrator designs also cover nearly all the different possible technical approaches listed previously, which indicates that the industry is still in its infancy and that a best approach has not been identified. While some companies are much further in development of their product than other companies, none of the firms listed has a production 
capacity greater than $1 \mathrm{MW} / \mathrm{Yr}$.

The status of concentrator collector techrology has been recently reviewed by both Boes and Richards et al. $(4,5)$. A technical conference partially devoted to photovoltaic concentrator collectors was also recently completed (6). These papers provided descriptions of the different collectors presently under development, of the major technical issues facing concentrator collector developers, and of the DOE concentrator collector program. For the purposes of this pape ${ }_{\perp}$, I would like to briefly review the most mature systems as represented by two major new installations and review some new prototype modules that are of interest due to their high performance or potentially low manufacturing cost.

ENTECH Inc. recently completed installation of a concentrator array in Austin, Texas (7). The system has been fully operational since March 1990. ENTECH uses an arched linear-focus Fresnel lens with a geometric concentration ratio of $22 \mathrm{x}$. The lenses were made from Lensfilm manufactured by $3 \mathrm{M}$ Corp. An important advantage of ENTECH's design is the arched lenses that have high optical efficiencies $(90 \%)$. The cells were manufactured by solarex corp. and have an average efficiency of $18.8 \%$ ( 25 suns, $\left.25^{\circ} \mathrm{C}\right)$. The measured output of the array at normal operating conditions $\left(60^{\circ} \mathrm{C}\right.$ cell temperature) is $260 \mathrm{~kW}$ dc with an array conversion efficiency of $13 \%$, which corresponds to a peak module efficiency of 15\%. (All peak module efficiencies reported in this paper are dc efficiencies referenced to $25^{\circ} \mathrm{C}$ cell temperature and $1 \mathrm{~kW} / \mathrm{m}^{2}$ direct normal insolation.) This is believed to be the highest conversion efficiency reported to date for a utility-scale photovoltaic plant.

Alpha solarco corp. completed installation of a sinall photovoltaic concentrator power system in the fall of 1989 (8). Its system uses an aluminum housing and a point-focus Fresnel lens (3M Lensfilm) with a geometric concentration ratio of $492 x$. The cells have an average efficiency of $19 \%$ and were manufactured by Applied Solar Energy Corp. The initial output of the array of $10 \mathrm{~kW}$ was much lower than expected due to solarization of the secondary optical 
element (SOE). A new glass has been

found for the SOE, and Alpha Solarco plans to retrofit the array. The company anticipates that the array will have a peak efficiency of $15 \%$ with its current cells.

The Alpha Solarco module is based on a design originally investigated at Varian Corp. and recentiy developed to production prototype status at Sandia Laboratories $(9,10)$. The key to low cost for the design is that the aluminum housing functions as the heat sink, which minimizes the number of parts in the cell assembly and penetrations of the module housing. Sandia's production prototype mini-module achieved a peak efficiency of 18\%, while an experimental module using a lens with an AR coating and the same cell assemblies achieved a peak efficiency of $20 \%(10,11)$. Varian has used a similar design to build a $1000 \mathrm{X}$ concentrator module using GaAs concentrator cells (12). The company achieved an efficiency of $22 \%$ at normal. operating conditions (i.e. cell temperature around $60^{\circ} \mathrm{C}$ ) for a two-cell mini-module.

Another interesting recent development is the renewed interest in dense-packed photovoltaic receivers, both with with reflective dish collectors and in a central receiver with a heliostat field $(13,14)$. By increasing the power output from each photovoltaic receiver, these systems have the potential to reduce the cost of the receiver portion of a concentrator collector significantly compared to distributed collector designs. These systems also use active cooling that yields a higher cell efficiency. While significant technical issues remain, studies have projected costs for these systems that meet the DOE long-term goal.

The above survey of concentrator collector technolog! has onl.y reported on a few modules and arrays. Whe important point of the survey is that concentrator collector designs have been identified that have high efficiency and potentially low cost. other important technical issues regarding photovoltaic concentrator collectors that were beyond the scope of the present paper include qualification testing, quality-assurance and quality-control procedures, and development of various key components besides the cell (particularly the lens and cell 
mounting procedures and cell assembly design). Interested readers are referred to the recent review papers $(4,5,6)$.

\section{Concentrator cells}

The concentrator cell represents approximately one-third of the cost of a typical concentrator collector while the cell efficiency is the dominant factor concerning collector performance $(3,4)$. Hence, much of the concentrator development effor't over the years has emphasized develupment of concentrator cells. King presented a review of concentrator cell technology at the previous conference in this series, so I will only describe recent developments (15).

It is convenient to discuss concentrator cells in terms of the three technology pathes introduced in Table 1: low, mid, and high. These three pathes correspond to different cell technologies. The cost/efficiency goals for the lowconcentration cell are believed to be consistent with one-sun cell fabrication technology. An aerospace-type silicon cell, which uses processes similar to integrated-circuits (e.g. patterned diffusions, evaporated metallizations, photolithography, etc.) is believed appropriate for mid-concentration cell cost/efficiency goals. III-V concentrator cells are believed to be appropriate for the high-concentration-cell cost/ efficiency goals.

Table 3 contains a summary of concentrator cell efficiencies measured at Sandia. There has been continued progress in concentrator cell efficiencies, with the most dramatic new cell result being the 35\%-efficient GaAs/GaSb MSMJ cell from Boeing (16). UNSW has also steadily increased the performance of silicon concentrator cells, with efficiencies of $23 \%$ for laser-grooved cell at low concentration and $24 \%$ for a rear-passivated cell (PERL) at one sun (17). The latter cell structure is expected to be able to reach $27 \%$ as a mid-concentration cell. Stanford has identified solutions to stability problems encountered with the backpoint contact silicon cell, with $26 \%$ efficient stable cells demonstrated (18).

The cell-efficiency goals of Table 1 have all been demonstrated. The dcminant remaining issue regarding concentrator 
cells is their cost. Many of the more interesting new results concern the manufacturability of high-efficiency cell designs. A recent detailed estimate of the cost of a laser-grooved process sequence, which is well suited for lowconcentration applications, found that it is cost competitive with conventional one-sun process sequences, but with a higher cell efficilency (19). Simplified process sequences have been identified for the oack-point contact cell with lower processing costs $(20,21)$. A recent development in GaAs celis is the use of germanium substrates that lower substrate and processing costs. Boeing projects that a GaAs/GaSb MSMJ cell can be cost effective with sufficient vertical integration, new cell designs and production equipment, and large production volumes (16).

\section{Concentrator Initiative}

As a result of the recent substantial improvements in concentrator cell efficiencies and progress in low-cost module designs, the DOE established the Photovoltaic Concentrator Initiative at Sandia Laboratories (2). The goal of the initiative is to promote development of concentrator photovoltaic collector systems to meet the DOE near-term goal of $12 \mathrm{k} / \mathrm{kWh}$. This is to be achieved through competitively placed, cost-shared, multiyear contracts with industry. The initiative consists of two major efforts: cell development and collector development. The goal of the cell development portion is to accelerate adoption in industry of recent laboratory advances in high-efficiency concentrator cells. The goal of the collector portion is to develop a concentrator collector that meets all technical criteria (performance, reliability, etc.) with a manufacturable design that meets cost goals in large production volumes ( $>10 \mathrm{MW} / \mathrm{Yr}$ ). The cost goals for $b$ ith cell and collector are given in Table 1 . Fifteen proposals were received for the cell development solicitation and thirteen proposals were received for the collector solicitation. A total of eight proposals was selected for further negotiations; public announcement of the selections is expected by November.

\section{Conclusion}


The status of concentrator collector technology and high-efficiency concentrator cell technology was reviewed. There has been continued progress in concentrator collector and concentrator cell performance. There has also been introduction of new collectcr and cell designs that retain high efficiencies with lower manufacturing costs. The continued progress in collector and cell performance and in development of costeffective designs gives us confidence that photovoltaic concentrator collectors will be the first photovoltaic technology to become cost-effective for utilityscale power plant applications.

\section{Acknowledgements}

The photovoltaic concentrator collector project at Sandia Laboratories is a team effort. I would like to acknowledge the contributions of P. Basore, E. Boes, J. Cannon, J. Chamberlin, C. Chiang, D. King, A. Maish, M. Quintana, E. Richards, D. Ruby, C. Stillwell, and M. Whipple.

\section{$\underline{\text { References }}$}

PVSC refers to Proceedings of the IEEE Photovoltaic Specialists Conference.

1. National Photovoltaics Program FiveYear Research Plan, 1987-1991, DOE/CH10093-7, May 1987. 2. J.L. Chamberlin and D.L. King, to be published in 21st PVSC (May 1990).

3. J.L. Chamberlin, 20th PVSC, 1353 (1988).

4. E.C. Boes, to be published in 21st PVSC (May 1990).

5. E.H. Richards, J.L. Chamberlin, and E.C. Boes, 19th Amer. Sol. Energy Soc., Austin, TX, 1990 .

6. D.S. Ruby, ed., 1990 DOE/Sandia Crystalline Photo. Techn. Project Review Meeting, SAND90-1821, Albuquerque, NII $(1990)$.

7. M.J. O'Neill et al., to be published in 21st PVSC (May 1990).

8. D.E. Carroll et al.., ibid.

9. Neil Kaminar, SAND85-7002,

Albuquerque, NM (Feb. 1986).

10. E.H. Richards et al., to be published in 2.1st PVSC (May 1990).

11. C.J. Chiang and E.H. Richards, ibid.

12. M.S. Kuryla et al., ibid.

13. K. Beninga, in reference 6 , pg. 59.

14. R. Swanson, private communication.

15. D.L. King, 4th Inter. Photo. Sci. \& 
Eng. Conf., 56j (1989).

16. L.M. Fraas et al., to be published in 21st PVSC (May 1990).

17. M.A. Green et al., ibid.

18. P.E. Gruenbaum et al., ibid.

19. J.H. Wohlgemuth, et al., ibid.

20. P. Verlinden et al., ibid.

21. R.A. Sinton et al.' 4 th Inter. Photo.

Sci. \& Eng. Conf., $565(\overline{1989)}$.

Figure 1. Allowable cell cost compatible with $12 \% / k W h$ levelized-energy-cost goal. 


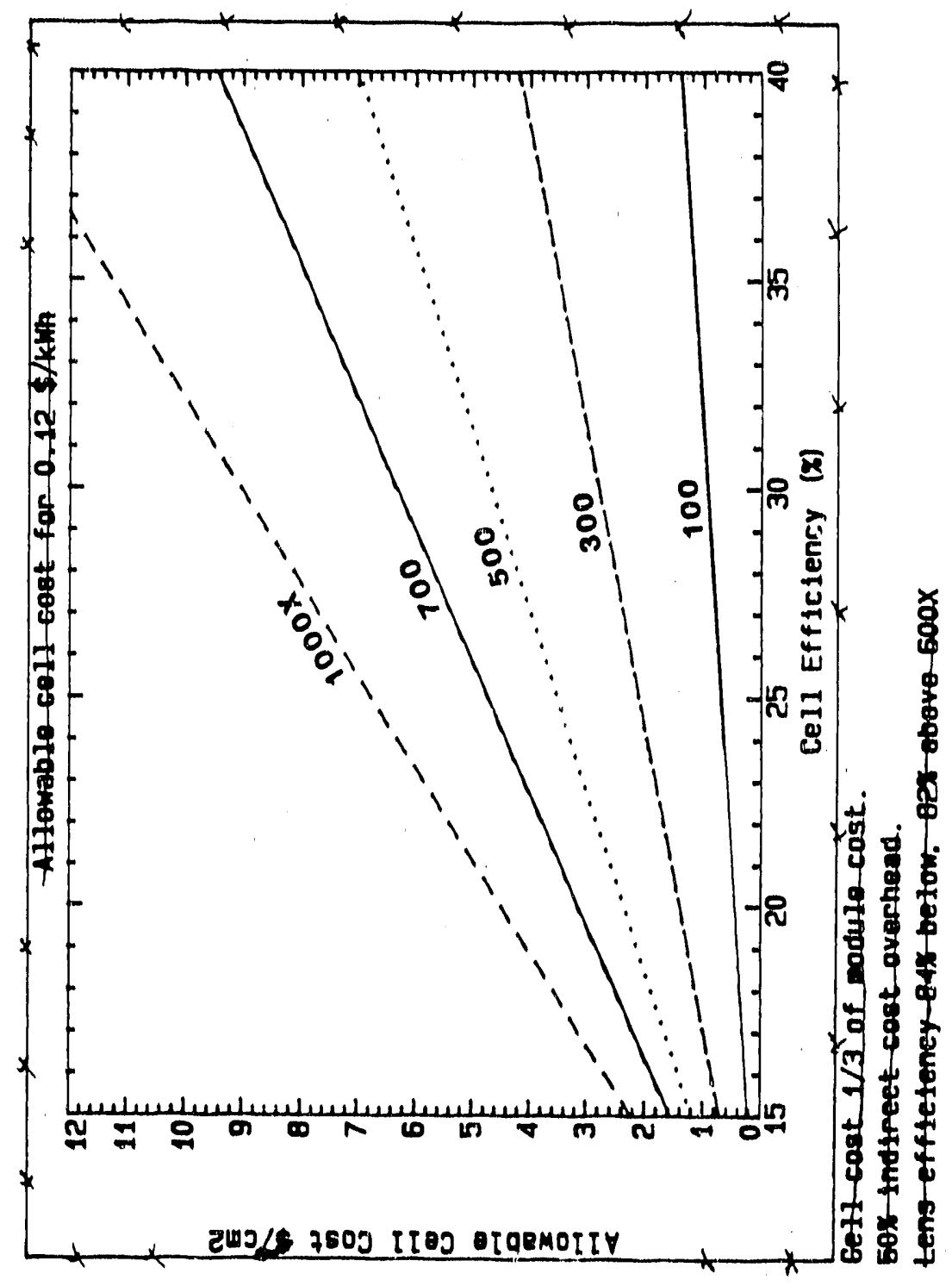


Table 1: Allowable module cost and estimated cell cost to achieve a levelized energy cost of $12, \mathrm{c} / \mathrm{kWh}$ as a function of peak module efficiency and concentration ratio, assuming an indirect cost of $50 \%$.

\begin{tabular}{|c|c|c|c|c|c|c|}
\hline \multicolumn{2}{|c|}{$\begin{array}{l}\text { Peak Module } \\
\text { Efficiency } \\
\qquad(q)\end{array}$} & $\begin{array}{c}\begin{array}{c}\text { Allowable } \\
\text { Module Cost } \\
(\$ / \mathrm{m} 2)\end{array} \\
91\end{array}$ & $\begin{array}{l}\begin{array}{l}\text { Assumed } \\
\text { Cel1 Eff. } \\
(z)\end{array} \\
\frac{11.4}{}\end{array}$ & \multicolumn{2}{|c|}{$\begin{array}{l}\text { Assumed } \\
\text { Conc.Ratio } \\
\text { (suns) }\end{array}$} & \multirow{2}{*}{$\begin{array}{l}\begin{array}{l}\text { Estimated } \\
\text { Cell Cost } \\
(\$ / \mathrm{Cm} 2)\end{array} \\
.0045 \\
.0089 \\
.0120\end{array}$} \\
\hline One-sun & $\begin{array}{l}10 \\
15 \\
20\end{array}$ & $\begin{array}{r}91 \\
178 \\
241\end{array}$ & $\begin{array}{l}11.4 \\
17.0 \\
22.7\end{array}$ & & $\begin{array}{l}1 \\
1 \\
1\end{array}$ & \\
\hline Low-X & $\begin{array}{l}15 \\
20\end{array}$ & $\begin{array}{l}112 \\
195\end{array}$ & $\begin{array}{l}17.2 \\
23.0\end{array}$ & $\begin{array}{l}10 \\
10\end{array}$ & $\begin{array}{l}-30 \\
-\quad 30\end{array}$ & $\begin{array}{l}.037-.112 \\
.065-.195\end{array}$ \\
\hline Mid-X & $\begin{array}{l}20 \\
25\end{array}$ & $\begin{array}{l}195 \\
278\end{array}$ & $\begin{array}{l}23.8 \\
29.8\end{array}$ & $\begin{array}{l}200 \\
200\end{array}$ & $\begin{array}{l}-400 \\
-400\end{array}$ & $\begin{array}{l}1.30-2.60 \\
1.85-3.71\end{array}$ \\
\hline $\mathrm{High}-\mathrm{X}$ & $\begin{array}{l}25 \\
3 C\end{array}$ & $\begin{array}{l}275 \\
360\end{array}$ & $\begin{array}{l}30.5 \\
36.6\end{array}$ & $\begin{array}{l}700 \\
700\end{array}$ & $\begin{array}{l}-1000 \\
-1000\end{array}$ & $\begin{array}{l}6.42-9.17 \\
8.40-12.00\end{array}$ \\
\hline
\end{tabular}


Table 2. Summary of photovoltaic concentrator collector development activities in the United states. PFF and LFF refer to point- and

linear-focus Fresnel lens, TIR refers to total internal reflection, and SOE refers to secondary optical element. 


\begin{tabular}{|c|c|c|}
\hline Developer & Description & status \\
\hline A.ESI & $\begin{array}{l}2 \times 5 \text { PFF, } 0.25 \mathrm{~m}^{2}, \text { plastic } \\
\text { housing, TIR SOE, } 350 \mathrm{X}\end{array}$ & $\begin{array}{l}\text { Several prototypes } \\
\text { have been fabricated. }\end{array}$ \\
\hline $\begin{array}{l}\text { Alpha } \\
\text { Solarco }\end{array}$ & $\begin{array}{l}2 \times 12 \text { PFF, } 1.25 \mathrm{~m}^{2}, \text { Al housing, } \\
\text { glass silo SOE, } 492 \mathrm{X}\end{array}$ & $\begin{array}{l}100 \text { first generation } \\
\text { modules installed. }\end{array}$ \\
\hline $\begin{array}{l}\text { Black \& } \\
\text { Veatch }\end{array}$ & $\begin{array}{l}4 \times 6 \text { PFF, } 0.7 \mathrm{~m}^{2}, 290 \mathrm{X}, \\
\text { reflective SOE. }\end{array}$ & $\begin{array}{l}\text { First prototype built, } \\
\text { under test. }\end{array}$ \\
\hline ENTECH & $\begin{array}{l}\text { Several designs based on } \\
\text { arched-LFF, } 10 \mathrm{X} \text { to } 40 \mathrm{X}, \\
\text { Al housing, } 1.5 \text { to } 3.0 \mathrm{~m}^{2}, \\
\text { prismatic coverglass. }\end{array}$ & $\begin{array}{l}\text { Several hundred modules } \\
\text { installed in several } \\
\text { systems, peak dc effi- } \\
\text { ciencies over } 15 \% \text {. }\end{array}$ \\
\hline EPRI & $\begin{array}{l}4 \times 12 \text { PFF module, } 500 x, \\
\text { back-point contact } \mathrm{Si} \text { cells }\end{array}$ & Several prototypes tested \\
\hline Midway Labs & $\begin{array}{l}91 X \text { PFF, Al housing, TIR SOE, } \\
4^{\circ} \text { tracking tolerance allows } \\
\text { passive tracking. }\end{array}$ & $\begin{array}{l}\text { Several modules built, } \\
\text { currently under test. }\end{array}$ \\
\hline SAIC/TFI & $\begin{array}{l}\text { Reflective dish concentrator, } \\
\text { PV receiver a dense array of } \\
\text { cells, active cooling. }\end{array}$ & $\begin{array}{l}\text { Dish and first experi- } \\
\text { mercal receiver currently } \\
\text { under test. }\end{array}$ \\
\hline Sandia SBM3 & $\begin{array}{l}2 \times 12 \text { PFF, } 185 x, \text { Al housing, } \\
0.7 \mathrm{~m}^{2} \text {, reflective sOE. }\end{array}$ & $\begin{array}{l}\text { Components and two proto- } \\
\text { type modules under test. }\end{array}$ \\
\hline $\begin{array}{l}\text { Sandia } \\
\text { Concept } 90\end{array}$ & $\begin{array}{l}\text { PFF, } 100 \mathrm{~cm}^{2} \text { lens, encapsula- } \\
\text { ted receiver, plastic housing, } \\
\text { back-point contact Si cells. }\end{array}$ & $\begin{array}{l}\text { Small prototype under } \\
\text { test, peak eff. of } 19 \%\end{array}$ \\
\hline $\begin{array}{l}\text { Sandia } 100 x \\
\text { Experimental }\end{array}$ & $\begin{array}{l}2 \times 5 \text { PFF, 100X, high-efficiency } \\
\text { demonstration module. }\end{array}$ & $\begin{array}{l}\text { Used to demonstrate } 20 \% \\
\text { module efficiency. }\end{array}$ \\
\hline SEA COrp. & $\begin{array}{l}\text { LFF using extruded acrylic } \\
\text { lens and housing, lox. }\end{array}$ & $\begin{array}{l}\text { Initial lenses and mini- } \\
\text { module fabricated and } \\
\text { tested. }\end{array}$ \\
\hline Sunpower & $\begin{array}{l}\text { Photovoltaic central receiver } \\
\text { using si back-point contact } \\
\text { cell in dense array. }\end{array}$ & $\begin{array}{l}\text { Systems cost study and } \\
\text { dense-packed receiver } \\
\text { design completed. }\end{array}$ \\
\hline SciTech & $\begin{array}{l}\text { Static low concentration } \\
\text { design using bifacial cells. }\end{array}$ & $\begin{array}{l}\text { First prototypes being } \\
\text { fabricated. }\end{array}$ \\
\hline SKI & Design similar to SBM3. & $\begin{array}{l}\text { Prototype being fabri- } \\
\text { cated. }\end{array}$ \\
\hline Varian & $\begin{array}{l}\text { PFF, I000X, Al housing, } \\
\text { TIR SOE. }\end{array}$ & $\begin{array}{l}\text { Mini-module tested with } \\
\text { peak eff. above } 22 \%\end{array}$ \\
\hline Wattsun & $\begin{array}{l}\text { Thin-profile module with } 11-\mathrm{mm} \\
\text { sq. lens and } 2.5-\mathrm{mm} \text { dia. cell. }\end{array}$ & $\begin{array}{l}\text { Several prototypes have } \\
\text { tested at } 11 \% .\end{array}$ \\
\hline
\end{tabular}


Table 3. Status of concentrator cells' efficiencies. High- $\rho$ and low- $\rho$ refer to high and low resistivity; FZ, PX, and $\mathrm{Cz}$ refer to float-zone, polycrystalline, and Czochralski; PCG refers to prismatic coverglass; and MSMJ refers to mechanically stacked, multijunction cell.

\begin{tabular}{|c|c|c|c|c|c|}
\hline Developer & Material & Cell Type & $\begin{array}{l}\text { Area } \\
\mathrm{cm}^{2}\end{array}$ & $\begin{array}{l}\text { Cone. } \\
\text { suns }\end{array}$ & $\begin{array}{c}\text { Eff. } \\
\frac{\%}{0}\end{array}$ \\
\hline \multicolumn{6}{|c|}{ Low-Concentration Cells } \\
\hline $\begin{array}{l}\text { UNSW } \\
\text { Solarex } \\
\text { Solarex } \\
\text { Astropower }\end{array}$ & $\begin{array}{l}\mathrm{FZ}, \mathrm{Si} \\
\mathrm{Cz}, \mathrm{Si} \\
\mathrm{PX}, \mathrm{Si} \\
\mathrm{Cz}, \mathrm{Si}\end{array}$ & $\begin{array}{l}\text { Laser grooved, PCG } \\
\text { LOW- } \rho, \text { PCG } \\
\text { Low }-\rho, \text { PCG } \\
\text { Low }-\rho, \text { PCG }\end{array}$ & $\begin{array}{l}20.0 \\
38.4 \\
39.5 \\
39.6\end{array}$ & $\begin{array}{l}20 \\
20 \\
20 \\
20\end{array}$ & $\begin{array}{l}22.6 \\
20.2 \\
17.5 \\
17.8\end{array}$ \\
\hline \multicolumn{6}{|c|}{ Mid-Concentration Cells } \\
\hline $\begin{array}{l}\text { Stanford } \\
\text { UNSW } \\
\text { SERA } \\
\text { Solarex }\end{array}$ & $\begin{array}{l}\mathrm{FZ}, \mathrm{Si} \\
\mathrm{FZ}, \mathrm{Si} \\
\mathrm{FZ}, \mathrm{Si} \\
\mathrm{FZ}, \mathrm{Si}\end{array}$ & $\begin{array}{l}\text { High- } \rho \text {, back contact } \\
\text { Low- } \rho \text {, PCG } \\
\text { High- } \rho \text {, back contact } \\
\text { Low }-\rho \text {, PCG }\end{array}$ & $\begin{array}{l}0.15 \\
1.58 \\
0.065 \\
1.58\end{array}$ & $\begin{array}{r}140 \\
125 \\
65 \\
150\end{array}$ & $\begin{array}{l}28.2 \\
25.2 \\
23.9 \\
21.5\end{array}$ \\
\hline \multicolumn{6}{|c|}{ High-Concentration cells } \\
\hline $\begin{array}{l}\text { Varian } \\
\text { Varian } \\
\text { Spire } \\
\text { Sandia } \\
\text { Boeing }\end{array}$ & $\begin{array}{l}\text { GaAs } \\
\text { GaAs } \\
\text { GaAs } \\
\text { GaAs/Si } \\
\text { GaAs/GaSb }\end{array}$ & $\begin{array}{l}\text { PCG } \\
\text { MSMJ, Varian, stanford } \\
\text { MSMJ }\end{array}$ & $\begin{array}{l}0.126 \\
0.126 \\
0.317 \\
0.317 \\
0.053\end{array}$ & $\begin{array}{l}403 \\
206 \\
200 \\
500 \\
100\end{array}$ & $\begin{array}{l}28.1 \\
29.2 \\
28.7 \\
31.0 \\
34.2\end{array}$ \\
\hline
\end{tabular}



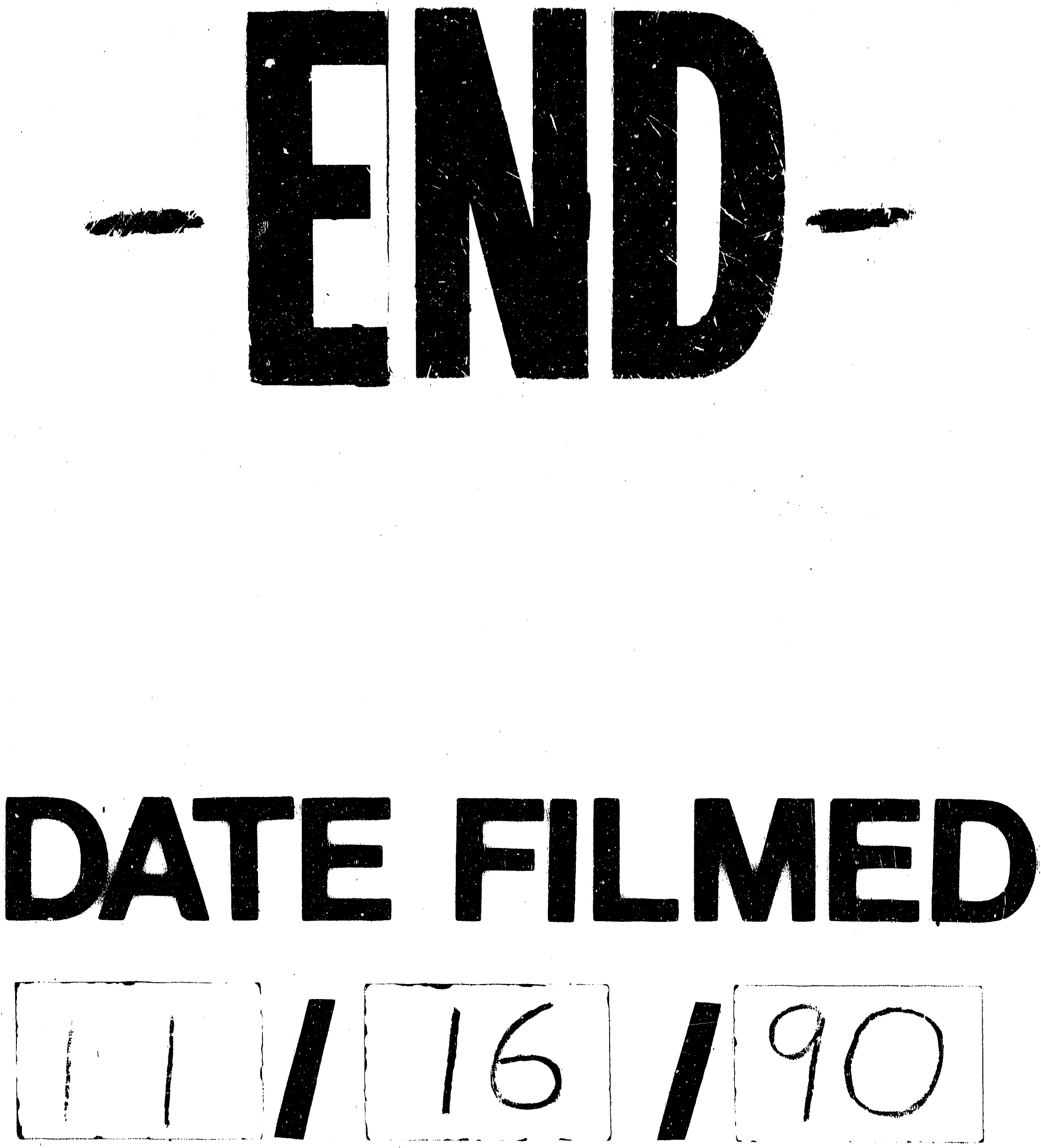
$\ldots \quad \ldots$

1
1
$\vdots$ 